\title{
AFIKSASI DAN REDUPLIKASI \\ PADA NAMA-NAMA MARGA ETNIS SANGIHE
}

Evi Martika D. Kasiahe

kasiaheevi@gmail.com

Rina P. Pamantung

r.pamantung@yahoo.com

Leika M. V. Kalangi

leikamvk17@gmail.com

\section{Pasca Sarjana Program Studi Linguistik Universitas Sam Ratulangi}

\begin{abstract}
Sangihe ethnic surnames have numerous morphological processes, but have not been a major concern for linguists. Previous research from Bawole (1981) regarding the morphology of Sangihe language also had not analyzed this issue. In this research, researchers analyzed names morphologically in particular affixation and reduplication. The data in this research were collected through two methods, namely observation method with the technique of observing by visiting village's office and collecting data regarding surnames. Secondly, interview with elicitation technique are employed to four informants to comprehend the meaning of the collected data of surnames. Data analysis was done through distributional method and was based on the morphological theory of Aronoff and Fudeman (2011). This research aims to explain three things, namely the affixation process and reduplication process of Sangihe ethnic surnames. In affixation it is found that a similar affix can produce different grammatical meanings depending on the class of words it adheres to and that Sangihe ethnic surnames found that a form of partial reduplication, namely repetition of the first phoneme of the basic form.
\end{abstract}

Keywords: morphology, surname, ethnic, sangihe

\section{LATAR BELAKANG}

Dalam studi morfologi, pembentukan sebuah kata dalam ditelusuri secara lebih mendalam dengan melihat proses morfologis yang membentuknya. Proses pembentukan kata secara morfologis dapat dirinci menjadi beberapa jenis, yaitu afiksasi, reduplikasi, komposisi, derivasi dan infleksi.Etnis Sangihe, salah satu etnis yang ada di Sulawesi Utara, memiliki nama marga dengan bentuk morfologis yang unik dan kompleks. Misalnya makawaehe, takaliuang, harimisa tiga marga ini dibentuk dari kombinasi morfem yang berbeda-beda makawaehe dibentuk dari dua morfem /makal + /waehel $\rightarrow$ makawaehe; takaliuang dibentuk dari tiga morfem /takal + /iul + lang/ Ttakaliuang; harimisa dibentuk dari dua morfem bebas yaitu /hari/ + /misa/. Karena itulah nama marga Etnis Sangihe diangkat sebagai objek dalam penelitian ini, melihat struktur 
internal sebuah kata dan bagaimana sebuah kata terbentuk dari kombinasi morfem baik lewat proses afiksasi maupun reduplikasi.

Belum ada penelitian Bahasa Sangir yang secara khusus memperhatikan proses morfologis pada nama-nama marga. Bawole (1981) menulis tentang morfologi Bahasa Sangir secara umum, tidak terbatas pada nama-nama marga saja. Penelitian tentang nama secara umum juga telah cukup banyak dilakukan, diantaranya Sibarani dan Tarigan (1993), Sugiri (2003), Sundari (2008), Sahid (2010), Kafaabilah (2018) tetapi hampir selalu analisisnya terbatas pada struktur eksternal atau pada aspek pemaknaan sebuah nama, belum banyak yang memperhatikan struktur internal sebuah nama dan mengkajinya secara linguistik. Padahal secara morfologis nama juga merupakan sebuah kata baik nama diri maupun nama marga. Nama dalam Ensiklopedi Bahasa diartikan sebagai kata atau frasa yang mengidentifikasi seseorang, tempat atau benda (Crystal, 2015). Karena merupakan sebuah kata, maka nama dapat ditelusuri dan dikaji secara linguistik berdasarkan proses pembentukannya dan unsur yang membentuknya.

Perlu ada pendekatan yang sedikit berbeda untuk mengkaji nama dari sisi linguistik murni bukan hanya secara eksternal saja tetapi juga secara internal dengan melihat strukturnya.Diantaranya dengan melakukan kajian secara morfologis terhadap bentuk dari sebuah nama untuk melihat bagaimana sebuah proses morfologis dalam mengahasilkan sebuah kata atau sebuah bentuk yang baru Aronoff dan Fudeman (2011).Proses morfologis diantaranya adalah afiksasi dan reduplikasi. Menurut Aronoff dan Fudeman (2011:17-18) afiksasi adalah proses pembentukan kata yang melibatkan awalan, akhiran dan sisipan. Sebuah afiks dapat melekat pada sebuah kata dasar dengan kategori yang berbeda-beda, misalnya dapat melekat pada kata benda atau pada kata sifat.

Afiksasi adalah proses morfologis dengan menambahkan imbuhan pada bentuk dasar, sehingga bentuk dasar tersebut memeroleh makna baru yang berbeda dengan makna leksikalnya. Aronoff dan Fudeman (2011:11) mengatakan bahwa setiap bentuk afiksasi dapat memberikan makna gramatikal yang berbeda pada kata yang dilekatinya. Bawole (1981:3) mendefinisikan afiksasi sebagai proses pembubuhan afiks pada satu bentuk, baik bentuk tunggal atau bentuk kompleks untuk membentuk satu bentuk lain yang lebih besar. Lebih lanjut lagi dijelaskan oleh Bawole (1981:15) setiap afiks memiliki fungsi masing-masing tetapi dalam bahasa Sangir ada afiks yang tidak dapat dijelaskan fungsinya. 
Afiksasi memiliki beberapa bentuk, yaitu prefiks, sufiks, infiks, konfiks dan simulfiks (Kridalaksana, 2007:28-29). Prefiks adalah proses pengimbuhan yang terjadi di awal sebuah kata dasar. Pembubuhan imbuhan pada awal kata dasar ini membuat sebuah kata dasar memiliki makna baru. Sufiks adalah imbuhan yang dilekatkan pada akhir kata dasar yang bisa saja merubah kelas kata dan memberi makna baru pada kata dasar. Infiks merupakan salah satu jenis imbuhan yang dibubuhkan di dalam atau di tengah sebuah bentuk dasar. Infiks disebut juga dengan sisipan. Konfiks diimbuhkan secara serentak atau bersamaan pada bentuk dasar. Simulfiks adalah gabungan dari dua macam imbuhan atau lebih yang tiap tiap unsurnya tetap mempertahankan arti dan fungsinya masing-masing.

Dengan berbagai latar belakang tersebut, maka dalam penelitian ini peneliti akan menjelaskan keunikan nama marga Etnis Sangihe secara morfologis sambil memberikan pembuktian bahwa nama-nama marga juga mengalami proses morfologis yang terstruktur dan bersistem.Penelitian ini hanya dikhususkan pada proses morfologis yang terjadi pada nama-nama marga Etnis Sangihe dan bertujuan untuk menjelaskan dua proses morfologis yaitu proses afiksasi dan proses reduplikasi.

\section{METODOLOGI}

Penelitian ini adalah penelitian deskriptif kualitatif. Dengan metode deskriptif maka dapat dideskripsikan dan dijelaskan proses afiksas dan reduplikasi yang terjadi pada nama-nama marga Etnis Sangihe. Pengumpulan data dilakukan dengan metode observasi dan metode cakap.Metode observasi teknik sadap dan teknik lanjutan catat dilakukan dengan mendatangi kantor-kantor desa di tiga desa untuk mengumpulkan data tertulis berupa nama marga. Metode cakap dengan teknik pancing dilakukan lewat proses wawancara dengan empat orang informan untuk menggali arti dari nama marga.Analisis data menggunakan metode agih (Sudaryanto, 1993). Penelitian ini memiliki dua sumber data yaitu data lisan dan tulisan.Data tulisan adalah nama-nama marga yang dikumpulkan dengan mendatangi kantor-kantor desa. Data lisan diperoleh dari informan yang dipilih sesuai kriteria yang disebutkan oleh Samarin (1967).Instrumen penelitian yang digunakan adalah alat tulis untuk menampung data lisan maupun tulisan yang diperoleh dari kantor desa dan dari informan. Populasi dari penelitian ini adalah seluruh nama marga yang ada di tiga desa tersebut, sedangkan sampel dipilih dari nama-nama marga tersebut sesuai dengan kebutuhan dan kepentingan analisis data. Penelitian ini dilaksanakan di tiga desa di Kecamatan 
Tabukan Utara, Kabupaten Sangihe yaitu Desa Pusunge, Desa Lenganeng dan Desa Talolang sejak bulan Desember 2018 sampai Februari 2019.

\section{PEMBAHASAN.}

Bagian ini akan menguraikan dua hal, yaitu 1) proses afiksasi pada nama-nama marga Etnis Sangihe dan 2) proses reduplikasi pada nama-nama marga Etnis Sangihe. Berikut ini uraiannya.

\section{Afiksasi}

Afiksasi merupakan suatu proses morfologis yang penting dan sering dijumpai pada banyak bahasa, proses afiksasi biasanya menyebabkan perubahan kelas kata (derivasi) dan berfungsi sebagai penanda waktu (Aronoff dan Fudeman, 2011:227). Pembentukan nama-nama marga Etnis Sangihe melibatkan sejumlah proses morfologis, termasuk diantaranya afiksasi yang dapat berupa prefiksasi, infiksasi, sufiksasi dan imbuhan gabung.

\subsection{Prefiksasi}

Prefiksasi adalah proses pengimbuhan dengan menambahkan imbuhan di depan bentuk dasar. Masing-masing awalan atau prefix akan menghasilkan makna gramatikal berbeda pada setiap kata yang dilekatinya(Aronoff dan Fudeman, 2011:111). Prefiks selalu berbentuk morfem terikat sehingga harus melekat pada sebuah morfem bebas, dan membentuk morfem bebas yang dilekatinya menjadi sebuah kata yang baru dengan makna gramatikal yang baru. Penelitian ini menemukan empat prefiks pada pembentukan nama-nama marga Etnis Sangihe. Berikut ini akan dijelaskan empat prefiks tersebut.

\section{a. Prefiks /maka-/}

Prefiks maka- ditemukan pada nama-nama marga Etnis Sangihe seperti makangiras, makaluase, makawimbang, makakendung, makaheming. Proses morfologis yang terjadi pada pembentukan nama marga etnis sangihe dengan prefiks maka dapat dirumuskan sebagai berikut.

$\begin{array}{llll}\text { Imakal } & + & \text { Ingiras/ } & \rightarrow \text { makangiras } \\ & & \text { 'ngilu' } & \rightarrow \text { 'membuat ngilu' } \\ \text { Pref. } & + & \text { Adj. } & \rightarrow \mathrm{V} \\ \text { Imakal } & + & \text { Mluasel } & \rightarrow \text { makaluase } \\ & & \text { 'senang' } & \rightarrow \text { 'membuat senang' } \\ \text { Pref. } & + & \text { Adj. } & \rightarrow \mathrm{V}\end{array}$




$\begin{array}{llll}\text { Imakal } & + & \text { /bimbang/ } & \rightarrow \text { makawimbang } \\ & & \text { 'semangat' } & \rightarrow \text { 'membuat bersemangat' } \\ \text { Pref. } & + & \mathrm{N} & \rightarrow \mathrm{V} \\ \text { Imakal } & + & \text { /heming/ } & \rightarrow \text { makaheming } \\ & & \text { 'senyum' } & \rightarrow \text { 'membuat tersenyum' } \\ \text { Pref. } & + & \mathrm{N} & \rightarrow \mathrm{V} \\ \text { Imakal } & + & \text { / kendung/ } & \rightarrow \text { makakendung } \\ & & \text { 'ingatan' } & \rightarrow \text { 'membuat teringat' } \\ \text { Pref. } & + & \mathrm{N} & \rightarrow \mathrm{V}\end{array}$

Prefiks maka- melekat pada kata sifat seperti ngiras 'ngilu', luase 'senang' dan bimbang 'semangat'. Proses pengimbuhan dengan menggunakan prefiks maka-memiliki dua pola yaitu 1) Pref.maka $+\mathrm{Adj} \rightarrow \mathrm{V}$, 2) Pref.maka $+\mathrm{N} \rightarrow \mathrm{V}$. Setiap kata yang terbentuk dengan menambahkan prefiks maka- di depan sebuah bentuk dasar adalah verba. Hal ini tetap berlaku bahkwa jika bentuk dasarnya berupa kata sifat ataupun kata benda. Prefiks maka memberikan makna gramatikal 'membuat'. Prefiks maka- juga memiliki alomorf makaw jika kata dasar yang dilekatinya memiliki fonem awal $/ b /$. Fonem $/ b /$ akan luluh menjadi $/ w /$ dan membentuk alomorf makaw. Perubahan fonem yang disebabkan proses morfologis ini disebut sebagai morfofonemik (Aronoff dan Fudeman, 2011:73).

\section{b. Prefiks /tama/}

Setelah prefiks maka- pada nama-nama marga Etnis Sangihe juga ditemukan prefiks lain yaitu prefiks tama-. Prefiks ini dapat dijumpai pada nama marga Etnis Sangige sepertitamalawe.

$\begin{array}{llll}\text { ltamal } & + & \text { llawel } & \rightarrow \text { tamalawe } \\ & & \text { 'stek ubi jalar' } & \rightarrow \text { 'tidak bisa merambat' } \\ \text { Pref. } & + & \mathrm{N} & \rightarrow \text { Adj. } \\ \text { Itamal } & + & \text { /senggel } & \rightarrow \text { tamakang } \\ & & \text { 'layar perahu' } & \rightarrow \text { 'tidak bisa melayang' } \\ \text { Pref. } & + & \mathrm{N} & \rightarrow \text { Adj. } \\ \text { Itama/ } & + & \text { Irobal } & \rightarrow \text { tamaroba } \\ & & \text { 'ubah' } & \rightarrow \text { 'tidak bisa diubah' } \\ \text { Pref. } & + & \mathrm{V} & \rightarrow \text { Adj. }\end{array}$




$\begin{array}{llll}\text { Itamal } & +\quad \text { /poes/ } & \rightarrow \text { tamapoes } \\ & \text { 'turun' } & \rightarrow \text { 'tidak bisa diturunkan' } \\ \text { Pref. } & +\quad \mathrm{V} & \rightarrow \text { Adj. }\end{array}$

Prefiks tama- mengandung makna 'tidak bisa me-' jika melekat pada kata benda, tetapi akan memiliki makna 'tidak bisa di-' jika melekat pada kata kerja. Jika Aronoff dan Fudeman (2011:11) mengatakan bahwa setiap bentuk afiksasi dapat memberikan makna gramatikal yang berbeda. Di siniditemukan bahwa satu prefiks yang sama dapat memiliki makna gramatikal yang berbeda tergantung pada kelas kata yang dilekatinya. Untuk prefiks tama- jika melekat pada kata benda makna gramatikal yang dihasilkan adalah tidak dapat membuat seperti yang disebut pada kata dasar, sedangkan jika melekat pada kata kerja, makna gramatikal yang dihasilkan tidak dapat dibuat seperti yang disebut pada kata dasar. Dari struktur pembentukan di atas dapat dikategorikan dua pola pembentukan nama marga dengan prefiks tama- yaitu 1) Prefik.tama-+ $\mathrm{N}$ $\rightarrow$ Adj. dan 2) Prefiks.tama- + V $\rightarrow$ Adj.

\section{c. Prefiks /pang-/}

Selanjutnya ditemukan juga prefiks pang pada nama marga pangandaheng.

$\begin{array}{rlll}\text { 1. Ipang/ } & +\quad \text { landaheng/ } & \rightarrow \text { pangandaheng } \\ & & \text { 'orang suka ribut' } & \rightarrow \text { 'suka membuat ribut' } \\ \text { Pref. } & +\quad \mathrm{N} & \rightarrow \text { Adj. } \\ \text { 2. Ipang/ } & +\quad \text { lalerang/ } & \rightarrow \text { pangalerang } \\ & \text { 'orang suka jalan-jalan' } & \rightarrow \text { 'suka jalan-jalan' } \\ \text { Pref. } & +\quad \mathrm{N} & \rightarrow \text { Adj. }\end{array}$

Prefiks ini melekat pada kata benda dan mengubahnya menjadi kata sifat, karena hasil akhirnya adalah berupa kata sifat. Proses ini disebut juga sebagai derivasi yaitu proses pembentukan kata yang turut mengubah kelas kata yang dibentuk (Aronoff dan Fudeman, 2011:159). Misalnya, dari kata yang semula adalah kata benda berubah menjadi kata sifat atau sebaliknya. Prefiks ini memberikan makna gramatikal 'kecenderungan' atau 'suka berbuat seperti yang disebut pada bentuk dasar'. Pembentukan nama marga dengan menggunakan prefiks tama- hanya memiliki satu pola yaitu 1) Pref.tama $+\mathrm{N} \rightarrow$ Adj. 


\section{d. Prefiks /ma-/}

Prefiks keempat yang ditemukan pada nama-nama marga Etnis Sangihe adalah prefiks ma-pada nama marga manamuri dan matantu.

$\begin{array}{llll}\text { Imal } & +\quad \text { /samuril } & \rightarrow \text { manamuri } \\ & & \text { 'di belakang' } & \rightarrow \text { 'sengaja menjadi } \\ & & \text { yang terbelakang' } \\ \text { Pref. }+ & \text { Adj. } & \rightarrow \text { Adj. } \\ \text { Ima/ }+\quad / \text { tantul } & \rightarrow \text { matantu } \\ \text { 'tentu' } & & \rightarrow \text { 'berpendirian tetap' } \\ \text { Pref. } \quad+\quad \text { Adj. } & \rightarrow \text { Adj. }\end{array}$

Prefiks ini juga melekat pada bentuk dasar yang berupa kata sifat dan mengubahnya menjadi kata kerja. Manamuri berasal dari bentuk dasar samuri yang berarti di belakang (berada di posisi paling belakang). Prefiks $m a$ - yang melekat pada kata ini memberikan makna gramatikal 'kesengajaan' sehingga nama marga ini berarti 'sengaja menjadi yang terkebelakang'. Dengan alasan hormanisasi titik artikulasi (Aronoff dan Fudeman, 2011:95) prefiks ini akan beralomorf menjadi man- jika fonem awal kata yang dilekatinya adalah /s/. Seperti tampak pada nama marga /ma + samuri/ menjadi manamuri. Pada nama marga matantu prefiks /ma-/ dipadukan dengan kata sifat tantu 'tantu'. Jika dilekatkan pada kata sifat maka, makna gramtikal yang diberikan bukan lagi kesengajaan melainkan memiliki sifat seperti yang disebut pada kata dasar.

\subsection{Infiks}

Pada nama-nama marga Etnis Sangihe, ditemukan juga imbuhan yang tidak lekatkan pada awal ataupun akhir kata tetapi di tengah, bentuk afiks seperti ini disebut sebagai infiks (Aronoff dan Fudeman, 2011:3). Pada nama-nama marga Etnis Sangihe ditemukan dua buah infiks yaitu infiks -im- dan -um-.

\section{a. Infiks /-im/}

Infiks -im- ditemukan pada nama marga simuhude, nama marga ini berasal dari kata suhude 'dorong' yang disisipi infiks -im- dan membentuk kata simuhude 'telah terdorong'. Jadi penyisipan infiks -im- memberikan makna duratif keberlangsungan yaitu 'telah'.

$$
\begin{array}{ll}
/ \text { suhude/ }+\quad / \mathrm{im} / & \rightarrow \text { simuhude } \\
\text { 'dorong' } & \rightarrow \text { 'telah terdorong' }
\end{array}
$$




$\begin{array}{rlll}\mathrm{V} & + & \text { Inf. } & \rightarrow \mathrm{V} \\ \text { /sakal } & + & / \text { im/ } & \rightarrow \text { simaka } \\ \text { 'naik' } & & & \rightarrow \text { 'telahnaik' } \\ \mathrm{V} & + & \text { Inf. } & \rightarrow \mathrm{V}\end{array}$

Infiks -im- dapat melekat pada kata kerja seperti pada struktur sebelumnya, tetapi di luar nama marga infiks ini jugadapat melekat pada kata benda. Infiks -im- menghasilkan kata kerja. Infiks -im- dapat melekata pada kata benda atau kata kerja infiks ini menghasilkan bentuk akhir berupa kata kerja seperti terlihat pada pola sebagai berikut 1) V + Inf.im $\rightarrow$ V dan 2) $\mathrm{N}+$ Inf.im $\rightarrow \mathrm{V}$. Bawole (1981:38) menjelaskan bahwa infiks ini tidak memiliki fungsi yang jelas. Tetapi dapat penelitian ini peneliti menemukan bahwa prefiks ini memiliki funsgi yang jelas yaitu sebagai penanda waktu lampau. Posisi penyisipan infiks - -im- yaitu sesudah fonem pertama sebuah bentuk dasar.

\section{b. Infiks /-um/}

Selain infiks -im- ditemukan juga infiks -um- pada nama-nama marga Etnis Sangihe seperti dumingan dan lumairo. Jika infiks -im- memberikan makna telah pada kata yang disisipinya, penyisipan infiks ini memberi makna 'akan'. Adapun kaidah infiksasi pada nama-nama marga etnis Sangihe berlaku secara konsisten baik infiks -im- maupun -um- disisipkan sesudah fonem pertama bentuk dasar.

$\begin{array}{llll}\text { /dingan/ } & + \text { /um/ } & \rightarrow \text { dumingan } \\ \text { 'teman' } & & & \rightarrow \text { 'akan menemani' } \\ \mathrm{N}+\text { Inf. } & \rightarrow \mathrm{V} \\ \text { /lairo/ }+ \text { lum/ } & \rightarrow \text { lumairo } \\ \text { 'tangis' } & & \rightarrow \text { 'akan menangis' } \\ \mathrm{N}+ & & \rightarrow \mathrm{V}\end{array}$

/-um-/ adalah merupakan infiks yang melekat pada morfem dingan menjadi /dumingan/. Selain melekat pada kata benda infiks -um- juga melekat pada kata kerja. Adapun pola pembentukan kata dengan infiks $-u m$ - adalah 1) $\mathrm{N}+$ Inf.-um- $\rightarrow \mathrm{V}$ dan 2) $\mathrm{V}+$ Inf.-um- $\rightarrow \mathrm{V}$. Prefiks ini berfungsi sebagai penanda waktu mendatang. Menarik bahwa dalam bahasa Sangir penanda waktu sekarang tidak menggunakan infiks lagi tetapi reduplikasi, misalnya lumairo 
'akan menangis', limairo 'telah menangis'dan lulairo 'sedangkan menangis' dengan penggulangan fonem awal bentuk dasar.

\subsection{Sufiks}

Setelah proses pengimbuhan yang berupa prefiksasi dan infiksasi. Proses morfologis lainyang juga ditemukan pada pembentukan nama-nama marga Etnis Sangihe adalah sufiks atau imbuhan yang diletakkan setelah bentuk dasar (Aronoff dan Fudeman, 2011:3). Sufiks pada nama-nama marga Etnis Sangihe, ditemukan pada nama marga pontolawokang. Berikut ini digambarakan proses pembentukannya

\begin{tabular}{|c|c|c|c|c|c|c|}
\hline \multirow[t]{2}{*}{1.} & $\begin{array}{l}\text { /ponto/ } \\
\text { 'ukiran' }\end{array}$ & + & $\begin{array}{l}\text { / lawo/ } \\
\text { 'banyak' }\end{array}$ & + & $/ k a r$ & $\begin{array}{l}\rightarrow \text { pontolawokang } \\
\rightarrow \text { 'ukiran akan diperbanyak' }\end{array}$ \\
\hline & $\mathrm{N}$ & + & Adj. & + & Suf. & $\rightarrow \mathrm{V}$ \\
\hline \multirow[t]{3}{*}{2.} & /poto/ & + & / kang/ & & & $\rightarrow$ potokang \\
\hline & 'potong' & & & & & $\rightarrow$ 'akan dipotong' \\
\hline & $\mathrm{N}$ & + & Suf. & & & $\rightarrow \mathrm{V}$ \\
\hline \multirow[t]{3}{*}{3.} & /kadodo/ & + & /kang/ & & & $\rightarrow$ kadodokang \\
\hline & 'kecil' & & & & & $\rightarrow$ 'akan dikecilkan' \\
\hline & Adj. & + & Suf. & & & $\rightarrow \mathrm{V}$ \\
\hline
\end{tabular}

Penambahan sufiks memberikan makna gramatikal 'akan di' pada kata dilekatinya. Sufiks - kang dapat melekat pada kata benda maupun kata sifat dengan pola 1) Adj. + Suf.-kang $\rightarrow \mathrm{V}$ dan 2) $\mathrm{N}+$ Suf.-kang $\rightarrow$ V. Pada Sufiks -kang juga terjadi proses derivasi. Sufiks -kang yang melekat baik pada kata benda maupun kata sifat akan mengubah kata yang dilekatinya menjadi kata kerja. Sufiks - kang juga memiliki beberapa alomorf . Jika kata yang dilekatinya memiliki fonem akhir /o/ maka menjadi - kang misalnya kadodokang 'akan dikecilkan'dan akan tetap - kang jika kata dasar yang dilekatinya berakhir dengan fonem $/ u$ / misalnya, birukang 'akan dibuat jadi biru'. Akan menjadi -keng jika fonem akhir kata yang dilekatinya adalah /a/ misalnya guwakeng 'akan dibesarkan'. Akan menjadi - ang jika fonem akhir yang dilekatinya adalah / $g$ / misalnya itugang 'akan dihitamkan'.

\subsection{Imbuhan gabung}

Setelah beragam afiks seperti prefiks, infiks, dan sufiks yang telah diuraikan sebelumnya, pada nama marga Etnis Sangihe ditemukan juga imbuhan gabung sepertitakaliwungangdan 
takasenggeheang. Imbuhan gabung atau disebut juga kombinasi imbuhan berbeda dengan konfiks. Konfiks merupakan imbuhan yang membentuk satu kesatuan dengan bentuk dasar serta memiliki kesatuan makna gramatikal. Sedangkan imbuhan adalah gabungan beberapa afiks.

$\begin{array}{lllll}\text { ltakal }+ & \text { /liwung } & + & \text { lang/ } & \rightarrow \text { takaliwungang } \\ & \text { 'lingkaran' } & & & \rightarrow \text { 'tidak bisa (akan)dikesampingkan' } \\ \text { Pref. }+ & \mathrm{N} & + & \text { Suf. } & \rightarrow \text { Adj. } \\ \text { ltakal }+ & \text { /scngehel } & + & \text { lang/ } & \rightarrow \text { takasenggehang } \\ \text { 'sentuh' } & & & & \rightarrow \text { 'tidak bisa (akan) disentuh' } \\ \text { Pref. }+ & \mathrm{V} & + & \text { Suf. } & \rightarrow \text { Adj. } \\ \text { ltakal }+ & \text { /hindang/ } & + & \text { leng/ } & \rightarrow \text { takahindangen } \\ \text { 'ambil' } & & & & \rightarrow \text { 'tidak dapat (akan) diambil' } \\ \text { Pref. }+ & \mathrm{V} & + & \text { Suf. } & \rightarrow \text { Adj. } \\ \text { ltakal }+ & \text { lepisel } & + & \text { lang/ } & \rightarrow \text { takapisang } \\ \text { 'timpah' } & & & & \rightarrow \text { 'tidak dapat (akan) menimpah' } \\ \text { Pref. }+ & \mathrm{V} & + & \text { Suf. } & \rightarrow \text { Adj. }\end{array}$

Nama marga takariwungan memiliki prefiks taka- dan sufiks -ang yang dapat dipisahkan menjadi dua bentuk dan memiliki makna gramatikal masing-masing takaliwung 'tidak dapat dikesampingkan' dan liwungang 'akan dikesampingkan'. Begitu juga pada nama marga takasenggeheangmemiliki prefiks taka- dan sufiks - ang yang dapat dipisahkan menjadi dua bentuk yang juga miliki makna gramatikal masing-masing takasenggehe 'tidak dapat disentuh' dan senggehang 'akan disentuh'. Hal ini membuktikan kedua nama marga Etnis Sangihe ini dibentuk lewat proses imbuhan gabung dan bukan konfiks. Pola pembentukan nama marga dengan imbuhan gabung taka- -ang dapat dirumuskan sebagai berikut 1)Pref.taka $+\mathrm{N}+$ Suf.ang $\rightarrow$ Adj. dan 2) Pref.taka $+\mathrm{V}+$ Suf.ang $\rightarrow$ Adj.

Nama marga takapisang sebenarnya terdiri dari tiga morfem yaitu taka-, epise, dan -ang. Tetapi fonem awal / $/$ / telah dilesapkan sehingga menjadi takapisang karena kesalahan dalam pengucapan. Sementara dan fonem akhir /d/ pada kata senggehe dilesapkan karena proses sufiksasi sehingga menjadi takasenggehang. Jika kata dasar yang dilekati oleh sufiks -ang memiliki fonem akhir /ð/ maka fonem ini akan luluh, sedangkan jika fonem akhir dari kata yang 
dilekati adalah /g/maka sufiks - ang akan beralomorf menjadi - eng. Alomorf ini disebabkan oleh titik artikulasi fonem yang saling bertemu (Aronoff dan Fudeman, 2011:76).

\section{Reduplikasi}

Reduplikasi adalah bentuk pengulangan baik terhadap seluruh bentuk dasar maupun sebagai bentuk dasar atau reduplikasi parsial (Aronoff dan Fudeman, 2011:106). Jadi yang diulang tidak berupa seluruh bentuk dasar, melainkan hanya sebagian yaitu dengan mengulangi morfem pertama pada kata dasar dengan penambahan fonem vokal /a/ dan / $/$. Seperti tampak pada nama-nama marga, paparang, papendang, papehe, bawulag, kakante, tatamang, sasuang, hahosellahose, lumairo.

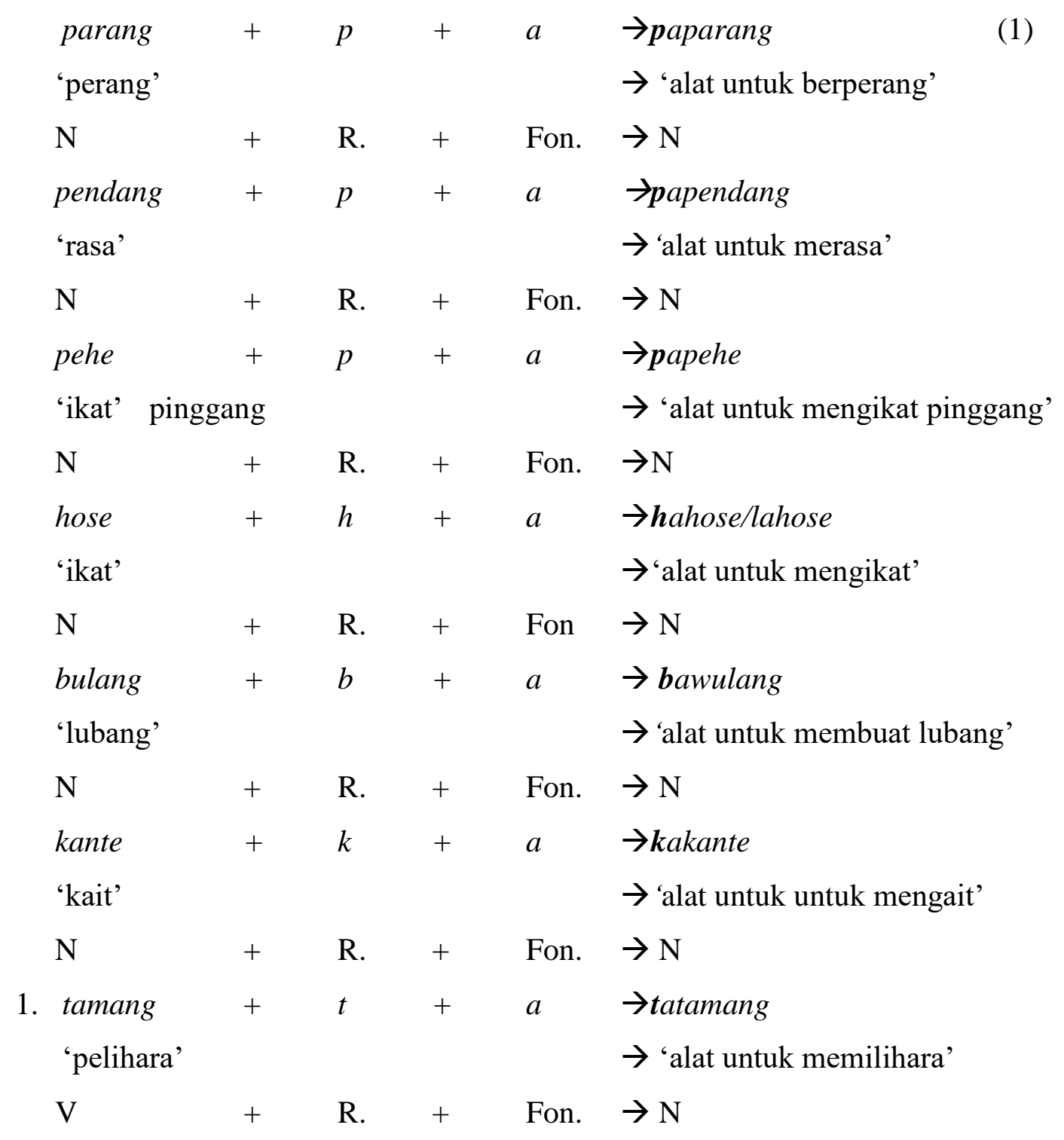




\begin{tabular}{|c|c|c|c|c|c|}
\hline suang & + & $s$ & + & $a$ & $\rightarrow$ sasuang \\
\hline 'tanam' & & & & & $\rightarrow$ 'alat untuk menanam' \\
\hline $\mathrm{V}$ & + & $\mathrm{R}$. & + & Fon. & $\rightarrow \mathrm{N}$ \\
\hline
\end{tabular}

Bentuk yang diulang adalah fonem pertama dari bentuk dasar. Nama marga paparang berasal dari kata parang 'perang' yang mengalami reduplikasi pada fonem $/ p /$ dengan penambahan vokal /a/ sehingga menjadi papaparang. Reduplikasi ini memberikan makna gramatikal 'alat' pada kata baru yang dibentuk. Jadi paparang berarti 'alat untuk berperang'. Bentuk nama marga lahose sebenarnya adalah hahose yang dibentuk dari pengulangan fonem $/ \mathrm{h} /$ dan penambahan vokal /a/ tetapi dituturkan menjadi hahose karena pengaruh dialek. Terjadi juga pengulangan fonem awal dengan penambahan vokal $/ u /$ memberikan makna gramatikal 'sedang berbuat'.

Dari struktur pembentukan kata lewat reduplikasi dapat dilihat bahwa reduplikasi dapat terjadi pada kelas kata benda maupun kata kerja dan mengubahnya menjadi kata benda. Dapat dirumuskan pada pola berikut 1) $\mathrm{N}+\mathrm{R}$. + Fon./a/ $\rightarrow \mathrm{N}$, 2) $\mathrm{N}+\mathrm{R}$. + Fon./a/ $\rightarrow \mathrm{N}$ dan 3) V + R. + Fon. $/ u / \rightarrow$ V.Bawole (1987) menjelaskan bahwa pada Bahasa Sangir hanya ditemukan jenis pengurangan seluruhnya baik dengan afiks atau tanpa afiks, lewat penelitian itu ditemukan bahwa pada Bahasa Sangir juga ditemukan jenis pengulangan sebagian seperti telah diuraikan pada uraian sebelumnya.

\section{SIMPULAN}

Berdasarkan penelitian dan serta pembahasan yang telah dipaparkan, maka berikut ini adalah kesimpulan yang dapat ditarik dari penelitian ini. Pertama, ditemukan prefiks (/maka-/, /taka-/, /tama-/, /pang/dan /ma-/); infiks (/-im-/ dan /-um/); sufiks (/-kang); dan imbuhan gabung (/taka-ang/). Kedua, reduplikasi ditemukan bentuk pengulangan sebagian yaitu pengulangan fonem awal kata dasar dengan penambahan fonem /a/ atau /u/. Hal ini membuktikan bahwa nama-nama marga Etnis Sangihe bukan hanya dipakai untuk menunjukkan identitas seperti penelusuran umumnya pada penelitian-penelitian terdahulu tetapi juga terbentuk lewat suatu proses morofologis yaitu afiksasi dan reduplikasi, yang memiliki pola dan terstruktur serta memungkinan untuk dilakukan analisis morfologis. 


\section{DAFTAR PUSTAKA}

Aronoff, M. 1994. Morphology by Itself: Stems and inflectional Classes. Hongkong: Massachussetts Institute of Technology. 1976. Word Formation in Generative Grammar. Cambridge, Mass: The Mit Press.

Aronoff, M. dan K. Fudeman. 2005. What is Morphology. USA: Blackwell Publishing

Baryadi, P. 2011. Morfologi dalam Ilmu Bahasa. Yogyakarta: USD.

Bawole, G dkk. 1981. Morfologi Bahasa Sangir. Jakarta: Pusat Pembinaan dan Pengembangan Bahasa Departemen Pendidkan dan Kebudayaan

Bloomfield, L. 2001. Language. London: George Alen \& Unwi LTD.

Booij, G. 2005. The Grammar Of Words. United States: Oxford University Press Inc.

Crystal, D. 2015. Ensiklopedi Bahasa. Bandung: Penerbit Nuansa Cendekia

Elson, B. dan V.Pickett. 1962. An Introduction to Morphology and Sintax. California : Santa Ana Chaer, A. 2008. Morfologi Bahasa Indonesia. Jakarta: PT Rineka Cipta.

Gleason, H. A. 1995. An Introduction to Descriptive Linguistics. New York: Henry Hold and Company.

Hock, H. H. 2009, Language History, Language Change, and Language Relationship. Mouton De Gruyter: Ohio.

I Dewa Putu Wijana. 2016. Bahasa dan Etnisitas: Studi Tentang Nama-Nama Rumah Makan Padang. Linguistik Indonesia. Vol.34 (2), hal.195-206.

Imbang, D. dkk. 2017. Bahasa Indonesia Akademik. Manado: Universitas Sam Ratulangi.

Kafaabilah, D. 2018. Nama Marga sebagai Identitas Budaya Masyarakat Etnis Arab. Litera. Vol. 17 (2), hal.175-185.

Kridalaksana, H. 2007. Pembentukan Kata dalam Bahasa Indonesia. Jakarta: Gramedia Pustaka Utama. 2008 Kamus Linguistik Edisi Keempat. Jakarta: Gramedia Pustaka Utama.

Lieber, R. 2009. Introducing Morphology. New York: Cambridge University Press.

Lyons, J. Terj. I Soetikno. 1995. Pengantar Teori Linguistik. Jakarta: Gramedia Pustaka Nusa Utama. 
Matthews, P. 1991. Morphology, second edition. Cambridge: Cambridge University Press.

McCharty dan A. Carstairs. 2002. An Introduction to English Morphology: Words and Their Structure. Edinburgh: Edinburgh University Press.

Michael, D. Dan O' Grady. 1987. Contemporary Linguistic Analysis: an Introduction. Paperback.

Nida, E. 1975. Componential Analysis of Meaning. Paris: Mouton. 1949. Morphology: The Descriptive Analysis of Words. Ann Arbor: University of Michigan Press.

Pamantung, R. P. Noun Derivation of The Typical Minahasa Food and Beverage Names. $e^{-}$ Journal of Linguistics. Vol. 9. (1), hal. 21-28.

Parera, J. D. 1988. Morfologi Bahasa. Jakarta: Gramedia Pustaka Utama.

Ramlan, M. 2001. Morfologi : Suatu Tindakan Deskriptif. Yogyakarta : C.V. Haryono.

Said, I. M.. 2018. “Analisis Morfo-Semantik Nama Diri Perantau Asal Etnis Mbojo (Bima) di Sulawesi Selatan Prosiding Kongres Internasional Masyarakat Linguistik Indonesia (KIMLI) 2018 hal. 139-145. Manokwari: MLI Universitas Papua.

Samarin, W. J. 1967. Field linguistics: A guide to linguistic field work. New York: Holt, Rinehart \& Winston.

Sibarani, R.dan H. G. Tarigan. 1993. Makna Nama dalam Bahasa Nusantara: Sebuah Kajian Antropolinguistik. Bandung: Penerbit Bumi Siliwangi.

Subroto, E. D. 1999. Ihwal Relasi Makna : Beberapa Kasus dalam Bahasa Indonesiadalam Telaah Bahasa dan Sastra. Jakarta : Pusat Pembinaan dan PengembanganBahasa.

Sudaryanto. 2015. Metode dan Anek Teknik Analisis Bahasa. Yogyakarta: Sanata Dharma University Press.

Sugiri, E. 2003. Perspektif Budaya Perubahan Nama Diri bagi WNI Keturunan Tionghoa di Wilayah Pemerintah Kota Surabaya. Bahasa dan Seni. Vol.31 (1), hal. 54-68.

Widodo, S. T. dkk. 2012. Nama Orang Jawa (Dinamika Perkembangan Bentuk dan Makna). Surakarta: Program Buku Teks Sebelas Lembaga Pusat Pengembangan Universitas Sebelas Maret.

Verhaar, J. W. M. 2010. Asas-asas Lingusitik Umum. Yogyakarta: Gadjah Mada University Press. . (1981). Pengantar Linguistik. Yogyakarta: Gadjah Mada University Press. 
Verhaar, J. W. M. 2010. Asas-asal Lingusitik Umum. Yogyakarta: Gadjah Mada University Press 